\title{
O PRINCÍPIO DA PUBLICIDADE E O PROBLEMA DA TRANSMISSÃO DE PROPRIEDADE NO DIREITO PRIVADO GREGO
}

\author{
Tiago Seixas Themudo \\ Professor do Programa de Pós-graduação em Direito \\ Privado e Relações Sociais do Centro Universitário 7 de \\ Setembro (UNI7), titular da cadeira de Antropologia \\ Jurídica à luz do Direito Privado. Doutor em Sociologia \\ pela Universidade Federal do Ceará - UFC. \\ E-mail: tiagothemudo@hotmail.com

\begin{abstract}
Adriano Pascarelli Agrello
Mestrando em Direito Privado pelo Centro Universitário 7 de Setembro (UNI7). Professor do Curso de Graduação em Direito da UNI7. Advogado.

E-mail: pascarelliadvogados@ hotmail.com
\end{abstract}

\begin{abstract}
RESUMO: A história do direito confere um lugar marginal ao direito grego clássico, sobretudo no que concerne ao campo do direito privado. A escassez das fontes arqueológicas e históricas, associada a efetiva falta de sistematização de seus códigos e práticas jurídicas, contribuiu para determinar esta posição secundária que a Grécia ocupa na história das instituições jurídicas ocidentais. Contudo, há exceções no campo da historiografia jurídica que lançaram luzes importantes sobre esta herança grega, que conheceu um desenvolvimento importante em várias cidades do período democrático. A escola francesa de história do direito, representada sobretudo pelas pesquisas de Ludovic Beauchet e Louis Gernet, elaborou, ao longo de quase cento e trinta anos, análises e descrições minuciosas das práticas judiciais gregas, inclusive do direito privado. $\mathrm{O}$ presente trabalho tem como objetivo analisar o contexto histórico em que se desenvolveu o direito privado grego, explorando seus vínculos com os fundamentos da democracia clássica, assim como suas ressonâncias com o direito moderno e contemporâneo. Mais especificamente, analisaremos a influência do princípio democrático da publicidade nas transferências de propriedade, sobretudo no direito privado ateniense. Para tanto, nos serviremos de fontes históricas clássicas, como a obra do filósofo Teofrasto, bem como de teorias interpretativas da dinâmica histórica que nos permitam compreender as criações específicas do campo do direito à luz das relações sociais e estruturas de poder surgidas na Grécia a partir do séc. VI a.C.
\end{abstract}

PALAVRAS-CHAVE: Democracia; Publicidade; Direito Privado; Propriedade; Grécia.

\section{The principle of publicity and the problem of transfer of property in Greek private law}

ABSTRACT: The history of law confers a marginal place on classical Greek law, especially in the field of private law. The scarcity of archaeological and historical sources associated with the actual lack of systematisation of their codes and legal practices has contributed to the determination of this secondary position which Greece occupies in the history of Western legal institutions. However, there are some exceptions in the field of legal historiography that have shed important light on this Greek heritage, which has seen important development in several cities of the democratic period. The French school of history of law, represented mainly by the investigations of Ludovic Beauchet and Louis Gernet, has elaborated for almost a hundred and thirty 
years detailed analyzes and descriptions of Greek judicial practices, including private law. The present work aims at analyzing the historical context in which Greek private law was developed, exploring its links with the foundations of classical democracy, as well as its resonance with modern and contemporary law. More specifically, we will analyze the influence of the democratic principle of advertising on property transfers, especially in Athenian private law. For this, we will use classic historical sources, such as the work of the philosopher Theophrastus, as well as interpretative theories of historical dynamics that allow us to understand the specific creations of the field of law in light of the social relations and power structures that emerged in Greece since the Century VI a.C.

KEYWORDS: Democracy; Publicity; Private right; Property; Greece.

\section{INTRODUÇÃO}

Há um certo consenso de que nossa tradição jurídica ocidental é herdeira, sobretudo, dos romanos. Apesar da ciência histórica ter consagrado o termo "cultura greco-romana", a parte que cabe aos gregos na história do direito é efêmera. Quando muito, reconhece-se a importância dos "fundamentos filosóficos" e morais do Estado republicano lançados pelos gregos, sobretudo através das obras de Platão e Aristóteles e do trabalho dos legisladores democráticos, como Sólon e Clístenes. Nesse sentido, a contribuição grega seria muito mais forte no campo das instituições políticas do que no campo das instituições e práticas jurídicas. É como se as instituições e práticas jurídicas fossem tão frágeis e insipientes na Grécia antiga que não teriam força para codificar o direito em outras civilizações. Há ainda quem reconheça uma certa importância da cultura grega na formação do direito público ocidental, reservando aos romanos a criação e desenvolvimento do direito privado.

No entanto, essa situação marginal do direito grego em nossa tradição jurídica parece não ser totalmente adequada. No caso do direito privado, por exemplo, somos herdeiro de todo um vocabulário jurídico criado pelos gregos: sinalagmático, no sentido de recíproco, e quirográfico, escrito à mão, além dos termos anticrese, enfiteuse, hipoteca, parafernais. O problema é que toda influência filológica pressupõe um vínculo das práticas institucionais no interior dos quais estes termos foram elaborados e utilizados.

O presente artigo, escrito no contexto da linha de pesquisa em direito privado, direitos humanos e desenvolvimento, do Programa de Pós-graduação em Direito Privado e Relações Sociais-UNI7, tem como objetivo inicial explorar as fontes históricas que permitem reconstituir o campo do direito privado nas cidades democráticas gregas, em especial, Atenas. Procuraremos analisar a maneira com que a democracia codificou, delineou, definiu o sentido das mais diversas áreas direito privado grego, direito de família, direito de propriedade e direto das obrigações.

Mais especificamente, estudaremos as formas de publicidade, um dos pilares do sistema da polis democrática, aplicadas às transferências de propriedade. A exigência legal de tornar público todo e qualquer ato de alienação de propriedade tem como função proteger os interesses de todos aqueles com direito real sobre o bem vendido. Dito de outra maneira, trata-se de um instrumento jurídico contra a fraude, contra a lesão dos direitos de um Outro considerado juridicamente como igual.

No entanto, esta análise não se sustentaria, nem se alinharia com a orientação da linha de nosso programa de Pós-graduação, sem articular as práticas jurídicas às relações sociais e estruturas de poder características da Grécia democrática. Só assim, a função prática do direito privado grego, bem como seu papel na mediação das relações de poder entre particulares poderá ser melhor compreendida. 


\section{O nASCIMENTO do ESTAdo JURÍdico na GrÉcia AnTIGa: DA DESMESURA À JUSTA MEDIDA}

A história das instituições democráticas na Grécia clássica, período que se estende do séc. VI ao séc. IV a.C., está intimamente vinculada ao violento conflito de classes que eclodiu após a queda do império micênico, provocas pelas ondas de invasão dórica. O súbito desaparecimento Ánax, rei micênico que concentrava em suas mãos todos os elementos do poder, fez com que forças sociais, antes sob controle, revelassem com toda a força suas contradições. "Da desigualdade profunda, a emergência de conflitos violentos entre camponeses pobres e proprietários de terra ricos" (FOUCAULT, 2014, p. 110).

A terra se encontrava dividida em porções bastante desiguais, apesar de inalienável, não podendo ser confiscada nem vendida; uma herança do "direito micênico", em que o Ánax era o único proprietário legítimo de todas as terras. Caso não houvesse herdeiros, as terras podiam simplesmente ser abandonadas, uma vez que não podiam ser comercializadas (VERNANT, 1992, FOUCAULT, 2014).

Esta enorme desigualdade fundiária, numa época em que a terra representava a fonte de toda a riqueza, levou a um aprofundamento da pobreza, pressionada pelo crescimento demográfico e por problemas no sistema produtivo, haja vista a ausência de irrigação perene e falta de planejamento. A baixa produtividade gerou um crescimento do endividamento do camponês pobre; e em caso de insolvência da propriedade, ela podia ser oberada, ou seja, um sexto dos rendimentos era dado ao credor, ou ainda, o devedor poderia ser escravizado. Dentre as mudanças significativas que o direto democrático instituiu, está a proibição da escravidão por dívida.

Aristóteles (2002, p. 41-42), em A construção de Atenas, descreve este estado de conflito anterior ao nascimento do Estado democrático ateniense da seguinte maneira:

[...] ocorreu por um longo período um conflito faccioso entre os notáveis e a multi-
dão. De fato, a Constituição era oligárquica em todos os aspectos, os pobres, bem
como suas esposas e filhos, sendo escravos dos ricos. Eram chamados de pelatai e
ektemoroi, pois esse era o aluguel que pagavam aos ricos para cultivarem as terras
desses últimos (o país inteiro estava na mão de poucas pessoas) e se deixassem de
efetuar o pagamento de seus aluguéis, ficavam sujeitos - eles e seus filhos - à prisão.
Até a época de Sólon, todos os empréstimos tinham como fiança a própria pessoa do
devedor. [...]. Assim, o que havia de mais difícil e mais amargo no tocante às coisas
públicas para a massa era o seu estado de escravidão. Na verdade, estava descontente
com relação a tudo o mais, pois realmente não partilhavam de coisa alguma.

Foucault (2014, p. 110) afirma que, apesar da estratégia da colonização para aliviar a pressão da pobreza nas cidades gregas, "a situação dos pobres piora". Esta contradição fundamental da sociedade grega não passará despercebida aos olhos dos filósofos gregos. Em $A R e$ pública, Platão escreve: "Cada cidade contém em si pelo menos duas cidades inimigas uma da outra: a dos pobres e a dos ricos (República, 422e)”. Aristóteles (2012, p. 35), na Política, nomeia da mesma forma os segmentos em oposição na cidade. "Na cidade, as duas classes mais distintas são os ricos e os pobres: são as partes da cidade mais opostas uma a outra".

Esse cenário originou disputas civis em praticamente todas as cidades gregas, e destes conflitos nasceram as transformações institucionais e espirituais que culminaram com a democracia, sobretudo, em Atenas. Apesar de diferenças no período em que tais conflitos ocorreram e as transformações que produziram entre as várias cidades gregas, como a prematura democracia em Quios, é possível identificar algumas características comuns. Quais as pautas da disputa civil que toma várias cidades gregas, e que terminará com a organização das polis democráticas, e no interior das quais emerge o direito privado grego como termo desta pauta? (FOUCAULT, 2014). 
Foucault afirma que a principal força de transformação na balança do poder foi o surgimento do hoplita, unidade militar surgida após a revolução do ferro trazida pelos dórios, e que implicou na inclusão, armamento e treinamento de todos aqueles que pudessem arcar com as despesas de suas armas, ou seja, justamente os pequenos proprietários que formavam o demos. Integrante da falange, principal força militar dos exércitos gregos, não demorará muito para que a importância militar se transforme em importância política. "Foi a força armada dos hoplita que mudou a balança do poder, inaugurando uma nova forma de soberania" (FOUCAULT, 2014, p. 116).

Não por acaso, as transformações foram favoráveis aos camponeses. O que não significa dizer a extinção das desigualdades. Dada a aliança entre uma parte da aristocracia e as classes populares, as transformações políticas e econômicas buscavam uma diminuição das desigualdades, a procura pela justa medida, pela proporcionalidade, pelo equilíbrio. Desta aliança - inclusive a que instituiu a democracia em Atenas, com Sólon, membro da aristocracia - não se produziu um regime de igualdade capaz de dar fim à luta de classes nas sociedades gregas, mas uma reestruturação do conflito. Nem tão ricos, nem tão pobres. Tal equilíbrio só poderia ser conquistado substituindo a arbitrariedade da vontade do mais forte, que só leva à desmesura, hybris, pela estabilidade da lei escrita, dike.

Dentre as mudanças podemos destacar, incialmente, uma modificação no sistema fundiário, seja através de uma reapropriação violenta das terras, do confisco ou exílio dos antigos proprietários, seja por uma redistribuição ou divisão das propriedades; ou o perdão das dívidas agrícolas. As práticas variam de cidade para cidade. Mas o importante é que as causas da desigualdade abissal são atacadas com extremo realismo, como forma de salvar a cidade da destruição, recolocando o próprio exercício do poder em novos termos. "No caso de Cípselo em Corinto, houve principalmente redistribuição de terras (a colocação em circulação de moedas deve ter possibilitado a extinção das dívidas); no caso de Sólon (em Atenas), ao contrário, houve perdão das dívidas, liberação das terras, mas não redistribuição [...]" (FOUCAULT, 2014, p. 116). À exceção das cidades em que prevaleceu a tirania como forma política que conduziu estas transformações, instaurou-se a hegemonia da lei escrita.

Em segundo lugar, fez-se necessário estabelecer todo um sistema de medidas que, antes de inspirar as reflexões filosóficas e produções estéticas dos gregos, possuía uma função prática em inúmeros campos da vida social. As formas de saber que desenvolveram toda uma cultura de quantificação, de não-excesso, de harmonia, de proporcionalidade, das "distribuições adequadas", de medida grega, articula-se a práticas sociais, a novas relações de poder que redefiniram, por exemplo, o problema do endividamento rural, da transferência de propriedade, a quitação de dívidas, a produção de hipotecas, " equivalência entre produtos alimentícios e ou objetos fabricados, [...] urbanização e implantação de uma forma estatal” (FOUCAULT, 2014, p. 120).

O estabelecimento de um direito privado em praticamente todas as cidades gregas derivou desta necessidade de codificar, de harmonizar, de estabelecer termos de proporção e justa medida às relações entre os diversos segmentos de sociedade em transformação. Não por acaso, a obra de Beauchet aborda áreas do direito privado diretamente ligadas aos problemas da propriedade, dos contratos, dos empréstimos, das hipotecas, das heranças, da produção, consumo e circulação de mercadorias. Sem um direito privado consistente e consideravelmente complexo, as sociedades gregas não teriam como impulsionar, por exemplo, o desenvolvimento do crédito e do comércio.

Importante destacar a profundidade e coerência deste projeto cultural. Impressiona como um paradigma, ao início com vocação claramente política, instaurar a ordem e a harmonia onde imperava o caos, a hybris, tenha se impregnado com tamanho sucesso em diversos campos da 
vida social e espiritual, desde os trabalhos de urbanismo de Hipodamo de Mileto, com a invenção da planta quadriculada das cidades, até as pesquisas de Pitágoras sobre as proporções das formas geométricas e das notas musicais, com a invenção da música harmônica (FOUCAULT, 2014).

Segundo Vernant (1992, p. 27), do âmago da crise, e em busca de um equilíbrio, de um acordo que impulsionasse a prosperidade das cidades gregas, desenvolveu-se uma reflexão moral e especulações políticas que vão definir uma "nova forma de "sabedoria" humana". Esta nova sophia, que começa a se sistematizar a partir do séc. VII a.C., e não tem, como fora o caso nos filósofos pré-socráticos, o mundo natural por objeto, a phisys, mas o mundo dos homens. As perguntas características desta sabedoria seriam: que elementos compõem a sociedade, que forças a dividem contra si mesma, como as harmonizar, unificar? O que deve ser feito para que, do conflito, surja a ordem superior da cidade? "Os problemas do poder, de suas formas, de seus componentes, foram repentinamente colocados em termos novos" (VERNANT, 1992, p. 27).

Nesta busca de unidade e harmonia, os antigos valores aristocráticos vão sendo substituídos pelos valores cívicos da justa medida. Nada em excesso! Eis a fórmula da cidade justa e próspera. Ao contrário, o transbordamento das vontades, a desmesura das paixões humanas será identificada como a raiz de todas as crises e males que assolavam a Grécia.

\footnotetext{
É a maldade dos homens, seu espírito de hybris, sua sede insaciável de riqueza que produzem naturalmente a desordem, segundo um processo de que se pode marcar de antemão cada fase: a injustiça engendra a escravidão do povo e esta provoca em troca a sedição. A justa medida, para restabelecer a ordem e a hesychie, deve, pois, ao mesmo tempo quebrar a arrogância dos ricos, fazer cessar a escravidão do demos, sem ceder por isso à subversão (VERNANT, 1992, p. 61).
}

A formação do Estado jurídico na Grécia integra este projeto e esta nova sabedoria, tanto no que concerne o direito público, quanto o privado. Veremos, por exemplo, que organização de um direito privado de propriedade, que prevê a necessária publicidade do ato como forma de conferir legalidade jurídica a compra e venda de propriedades, tem como objetivo evitar a fraude, a grilagem, o prejuízo a terceiros, logo, a injustiça, entendida como quebra da harmonia, desproporção, excesso.

Neste sentido, vale destacar que o desenvolvimento do Estado democrático grego, o sistema da polis, esteve apoiado sobre três pilares básicos. Primeiro, a preeminência da palavra como forma de legitimação de todo poder político e jurídico. Palavra entendida não como fala real ou fórmula mágica ritual de revelação, mas como força de persuasão, de argumentação racional, o debate contraditório - Peithó. Qualquer decisão política ou jurídica, elaborada fora de um espaço público de debate e confronto institucionalizado de ideias perde toda a legitimidade.

Em segundo lugar, a criação de um sistema associativo, entendido como um conjunto de normas e instituição de regulam as relações entre os indivíduos, de caráter igualitário, destinado e estimular relações de reciprocidade entre semelhantes, visando preservar a unidade da polis. Em substituição às antigas relações hierárquicas de submissão e domínio, essencialmente desproporcionais - fonte de toda a injustiça - relações equilibradas entre $i s o i$, entre iguais. A isonomia, igualdade abstrata de todos perante a lei, apesar das oposições e desigualdade da realidade social, inclusive nas democracias, coloca a todos os cidadãos no mesmo plano político, submetidos a um sistema cuja lei é o equilíbrio, "cuja norma é a igualdade” (VERNANT, 1992, p. 42). Invenção grega: todos são iguais perante a lei!

Em terceiro lugar, e este é o princípio que mais nos interessa no contexto deste artigo, a elaboração de espaços de plena publicidade para todas as questões que concernem o exercício do poder político e jurídico, seja público ou privado. “[...] práticas abertas, estabelecidas em plana luz do dia, opondo-se a processos secretos. Essa exigência de publicidade leva a apreender progressivamente em proveito do grupo e a colocar sob o olhar de todos o conjunto das condutas, 
dos processos [...]" (VERNANT, 2014, p. 34). É a fraude que se quer combater, a inclinação de enganar o outro não dando a conhecer seus direitos, a intimidação privada praticada longe do olhar de todos. Não era outra a queixa de Hesíodo contra seu irmão Perses que, excedendo-se em seus direitos, hybris, frauda a parte da herança que cabia ao poeta beócio, mergulhando-o na pobreza. O clamor é pelo abandono da injustiça e pela reta prática da justiça, ou seja, a temperança e a serenidade da justa medida, a cada um aquilo que lhe é devido (JAEGER, 1986, HESÍODO, 1990). No contexto jurídico do direito privado ateniense, Hesíodo certamente não teria perdido as terras que recebeu de herança de seu pai devido às trapaças de seu irmão.

Esta exigência de publicidade irá codificar praticamente todas as áreas do direito privado grego, assim como o paradigma do equilíbrio e da proporcionalidade, indo do direito de família, passando pelas regras de transferência de propriedade, e chegando até a regulamentação jurídica dos contratos. Vale aqui destacar que esta plena publicidade será completada através da escrita das leis. Ela que dará a estabilidade a dike e a capacidade de transformar a cultura das leis numa cultura comum, acessível a todos. "A história da codificação do direito nas diversas cidades gregas processa-se por vários séculos e sabemos muito pouco sobre ela. Mas é aqui que encontramos o princípio que a inspirava. Direito escrito era direito igual para todos, grandes e pequenos" (JAEGER, 1986, p. 91). A criação, no direito privado ático, dos livros de registro fundiário, anagrafe, conferiu perfeição às práticas publicitárias exigidas no direito de propriedade, sobretudo em Atenas e Thurum (BEAUCHET, 1897).

\section{Direito Privado e democracia na Grécia Clássica: o PRINCÍPIO DA PUBLICIDADE NA TRANSFERÊNCIA DE PROPRIEDADE}

Apresentado como um dos pilares fundamentais do sistema democrático grego, o princípio da publicidade organizou, desde muito cedo, o direito privado no que concerne às transferências de propriedade. Apesar de uma grande variação entre as cidades no que concerne às práticas adotadas, pode-se afirmar que em todas elas os contratos de compra e venda de propriedade precisavam tornar-se públicos e notórios para ganhara legitimidade jurídica. Já o direito romano, segundo Beauchet, não organizou um sistema completo de publicidade das transferências de propriedade, embora ele reconheça que toda transação supusesse uma "certa notoriedade", o que não significava que o interesse de terceiros se encontra protegido (BEAUCHET, 1897).

Esta constatação é reforçada por Gilissen (2013, p. 78), que reconhece, inclusive, assim como fez Beauchet, a dívida do direito privado moderno com o direito privado grego no que concerne aos sistemas de transcrição das vendas de bens imóveis.

\footnotetext{
[...] a transferência da propriedade realiza-se em direito grego apenas por efeito do contrato; mas este efeito é limitado às partes; em relação a terceiros, é organizado um sistema de publicidade parecido com o nosso sistema de transcrição dos actos. A proteção de terceiros é assim melhor assegurada na Grécia do que em Roma, onde esta publicidade não existia; [...]
}

Acreditamos que a afirmação de que a publicidade dos atos de venda de propriedade não existia em Roma é extremada, embora fosse, se comparada ao que existiu nas cidades gregas, descontínua e imperfeita. Pode-se citar como exemplo a mancipatio, uma das formas mais importantes de publicidade do direito privado romano, espécie de forma arcaica de registro predial. Segundo este ritual jurídico, a alienação da propriedade deveria acontecer na presença de 5 testemunhas, representando as diversas classes do povo, e de um jure cessio, um magistrado. Estas 
eram as duas formas de publicidade parcial que englobavam a aquisição de todas as coisas consideradas importantes no direito privado romano.

Mas estas práticas foram sendo progressivamente sendo substituídas pela traditio, prática jurídica que pode ser desprovida de toda notoriedade sem perder sua legitimidade. Neste sentido, pode-se considerar que a publicidade no direito privado romano, no que concerne às transferências, fora passageira e inconstante. Era preciso, por exemplo, na ausência de registros fundiários em Roma, "[...] apelar à memória das testemunhas, obrigatórias ou fortuitas, do ato jurídico realizado em sua presença, submetendo-se a todos os inconvenientes e perigos da prova testemunhal" (BEAUCHET, 1897, P. 320).

Já nas repúblicas gregas havia grande preocupação em garantir, de maneira mais ou menos completa, pelo menos no que concerne à transferência de bens imóveis, a plena publicidade. Os meios e as formas desta publicidade variavam de acordo com as cidades, mas a finalidade a que este princípio se propunha, a função social para a qual fora inventado era a mesma, ou seja, a proteção dos interesses de terceiros contra a fraude. Em algumas delas, havia uma publicidade semelhante àquela dos romanos, mesmo que mais ampla; em outras, como em Atenas, já verificava a existência de livros fundiários para registro de todas as transferências de propriedade, prática incorporada em vários códigos civis da Europa apenas no séc. XIX de nossa era (BEAUCHET, 1897).

Mas por que Roma não desenvolveu a prática da publicidade jurídica aplicada às transferências de propriedade? Por que os registros fundiários, tão úteis no estímulo do comércio e do crédito, não floresceram em Roma? Duas causas. Em primeiro lugar, o valor jurídico da escrita era bastante diferente entre gregos e romanos. Nas cidades democráticas gregas, havia uma implicação íntima entre publicidade e escrita dos atos jurídicos. "De um lado, a escrita, considerada como um meio de prova, sempre teve na Grécia mais importância do que em Roma, apegada sobretudo à solenidade de certos atos, contando com a memória das testemunhas instrumentárias" (BEAUCHET, 1897, p. 321). Em segundo lugar, quando da invasão da península ática pelos romanos, os próprios fundamentos da democracia grega já se encontravam em declínio.

[...] no momento em que os Romanos entraram na Grécia, o sistema da publicidade oficial dos contratos começava a perder terreno. [...] A inscrição das constituições dotais parece ter terminado desde o século II a.c. Quanto às transações imobiliárias, o hábito de transcrevê-las em registros públicos será conservado por mais tempo. Ele ainda vigorava na Ásia, no tempo de Cícero, mas Cícero também nos ensina que em Roma ele fora substituído pelos registros do censo. Quando a administração romana estendeu a instituição do censo a todas as províncias do império, todos os outros meios de publicidade foram abandonados (BEAUCHET, 1897, p. 321).

O texto de Beauchet nos oferece uma descrição detalhada de todas as práticas do direto privado grego destinadas a dar publicidade às transferências de propriedade, deixando por último a análise dos registros fundiários atenienses, que também surgiram tardiamente dentre as práticas judiciais criadas na Grécia. Pode-se afirmar que houve um processo de evolução, de aperfeiçoamento, nas diferentes formalidades legais.

No início, estas práticas jurídicas estavam ainda misturadas a elementos religiosos, organizadas segundo certas formalidades legais arcaicas. Uma época em que pé-direito e direito ainda não haviam definido fronteiras claras na cultura grega (GERNET, 1982). Muitas destas formas foram herdadas pelos romanos e preservadas em algumas cidades gregas. Tratava-se de sacrifícios e juramentos, ou conferir uma pequena moeda de prata ao vizinho, confirmando o caráter religioso da propriedade na Grécia. Segundo Fustel de Coulanges, citado por Beauchet (1987, p. 321-322), 


\begin{abstract}
Nas épocas antigas e em todos os povos, diz Fustel de Coulanges, a transferência da propriedade fundiária fora reputada coisa grave e fora, consequentemente, cercada por formas solenes. A mancipatio dos Romanos, a balança e o pedaço de couro, a presença de cinco testemunhas e do libripens são os restos de um velho procedimento sacramental utilizado pelas populações italianas. O sacrifício, o juramento, o pedaço de couro colocado nas mãos dos vizinhos são provavelmente também os restos de um procedimento sacramental utilizado pelos Gregos. Era natural que a venda da terra e a transferência da propriedade, por terem sido, nas épocas antigas, ou proibidas ou ao menos muito dificultadas, só pudessem acontecer através de formas complicadas e solenes.
\end{abstract}

A principal fonte histórica utilizada por Beauchet em sua classificação das formas de publicidade nas transferências de publicidade, sobretudo no séc. IV a.C., foi a obra do filósofo grego Teofrasto de Eressos, $O$ tratado das leis, infelizmente ainda não traduzido para o português. Em algumas cidades gregas, a publicidade das transferências de propriedade deveria ser:

1) Anunciada por um arauto público que, durante vários dias, deveria informar a todos da realização da transação.

2) Realizada na presença de um magistrado, cuja audiência era acompanhada pelo público. Beauchet faz referência a um caso concreto ocorrido em Metímna "[...] Pítaco queria que a venda acontecesse diante do basileus, o rei, e dos prítanes", considerados os mais altos magistrados das cidades gregas (BEAUCHET, 1897, p. 324).

3) Oficializada na presença dos vizinhos. "Em Thurium, segundo uma lei de Charondas, os três vizinhos mais próximos deveriam assistir a troca de consentimentos e lhes era rendida uma pequena moeda "em memória e em testemunho do ato" (BEAUCHET, 1897, p. 325). As testemunhas não são aqui aquelas que chegaram primeiro ao local do ato jurídico, não são escolhidas ao acaso dentre os transeuntes fortuitos. Elas são, ao contrário, designadas antecipadamente em relação ao seu domicílio, para que seja fácil encontrá-las "quando for necessário apelar às suas lembranças” (BEAUCHET, 1897, p. 326). As testemunhas não atuam como garantidores da venda, e interveem apenas a título de testemunha. Sua presença funciona como um meio de publicidade e, por isso mesmo, um instrumento contra a fraude nestas transações, para impedir, por exemplo, a venda simulada.

4) Informada através de proclamações públicas que deveriam durar cinco dias, como em Cýsico, na Ásia menor. Esta prática cumpria ainda a mesma função das descritas anteriormente, ou seja, criar condições jurídicas para que todos aqueles com direito real sobre a propriedade possam tomar conhecimento da venda. Essa era uma prática incondicional para a completa e legítima alienação do imóvel. Trata-se, como já foi dito, uma forma de proteção de terceiros contra a fraude, a injustiça.

5) Legitimada através de um sacrifício sobre o altar de Apolo, evidenciando, mais uma vez, a presença de elementos religiosos nas práticas jurídicas gregas. Nestes casos, vários sistemas de publicidade se encontravam misturados, na medida em que, além do local sagrado, a venda deveria ocorrer também na presença de três testemunhas locais. E mais, o comprador deveria jurar solenemente que contratava lealmente, sem desonestidade ou conluio.

Aquele que comprasse uma casa sem a intenção de habitá-la, quer dizer, para alugar, deveria oferecer seu sacrifício a Zeus Agoraios. Quando o bem vendido tinha apenas um valor módico, a oferenda consistia apenas em alguns bolos cobertos com mel. O magistrado deveria recusar o registro da venda enquanto estas formalidades não fossem cumpridas, e no juramento que ele mesmo prestava antes de ser investido na função, se comprometia a nunca registrar uma venda antes de receber das partes o juramento prescrito pela lei (BEAUCHET, 1897, p. 326). 
6) Cartazes fixados em lugares públicos previamente à conclusão da venda, paragrafa, como era o caso de Atenas. As inscrições eram feitas em quadros brancos, ou sobre placas de madeira revestidas de giz. Eles continham, segundo as poucas fontes arqueológicas que chegaram até a era moderna, "a designação do bem vendido e o nome do comprador" (BAEUCHET, 1897, p. 328). Os cartazes deveriam ser inclusive fixados no lugar em que trabalhava o magistrado por, pelo menos, dois meses, para que seja possível a qualquer um contestar a alienação. Este sistema de cartazes também era utilizado para dar publicidade à venda de escravos.

Estes sistemas de publicidade quase sempre eram praticados nas cidades quando falhavam, ou inexistiam, outras prescrições legais, como os registros fundiários, que já continham nesta época informações do imóvel e do contrato. Segundo Teofrasto, nas democracias gregas em que se verificavam a presença de registros fundiários, "pode-se descobrir por estes registros se os bens estão livres e sem multas, e se o vendedor os alienou regularmente, pois nestes países o magistrado inscreve imediatamente o comprador" (BEAUCHET, 1897, p. 328).

A instituição dos livros fundiários representou uma das grandes inovações do direito privado grego, incorporado, como já foi dito, no código civil francês, por exemplo, apenas no final séc. XIX. Este sistema completo de publicidade era chamado de anagrafe, e funcionava como uma espécie de estado civil das propriedades na Grécia. Estes registros permitiam, por exemplo, saber se o bem pertencia ao alienador ou se havia multas reais a serem pagas. Apesar de Teofrasto afirmar que a anagrafe era mais rara do que os outros sistemas de publicidade nas repúblicas gregas, Aristóteles (2011) afirmava serem frequentes estes registros.

Alguns destes registros fundiários de que fala Teofrasto chegaram até nós. Eles eram reunidos e gravados em grandes placas de mármore, como em Tinos e Míconos, e eram expostas em um lugar público. O exemplo mais completo é o da cidade de Tinos, mas também há listas de compradores de imóveis em registros das cidades de Quios, Acarnânia e Iasos, mesmo que os registros de vendas sejam mais difíceis de encontrar.

\begin{abstract}
Os registros onde eram mencionadas as vendas e as constituições de dote eram mantidos, muito provavelmente, pelos astinomos, magistrados encarregados da polícia urbana e da estrada. No registro, eram cuidadosamente anotados o nome do arconte, o nome do mês e do calendário. $\mathrm{O}$ extrato dos atos nele inseridos era redigido seguindo uma fórmula mais ou menos uniforme e mencionando, quando se tratava de uma venda, o imóvel vendido, sua situação, o preço da venda, o vendedor e o comprador - e, na ocasião, o estabelecimento da propriedade, - o sinal pago sobre o preço, as pessoas participantes da venda, seja para dar sua autorização, para consentir, seja para garantir o contrato (BEAUCHET, 1897, p. 330).
\end{abstract}

É muito rara, nestes registros, a menção da existência de hipotecas onerando os imóveis, fato que indica a existência de outro registro elaborado para esta finalidade. Trata-se dos óroi, registros hipotecários de que trataremos em outra publicação. Segundo Aristóteles (2012), o direito privado ateniense também previa a transcrição de todos os contratos e julgamentos. Mas vele lembrar que não bastava a simples elaboração do contrato de venda para que o magistrado realizasse a inscrição nos livros fundiários, dando legitimidade final à alienação. Como já fora exposto anteriormente, "a lei deveria acordar aos terceiros um certo tempo para efetuarem sua intervenção, se encaminharem ao gabinete do magistrado, contestarem a transcrição ou retificála, de forma a preservar seus direitos" (BEAUCHET, 1897, p. 331). Novamente, temos a preocupação grega em evitar a hybris criando as condições jurídicas de efetivação da dike, a lei da justa medida que garante a cada um o que lhe cabe de direito.

É relevante questionarmos se, na ausência de oposição de terceiros, o magistrado podia registrar a transferência de propriedade sem examinar os títulos apresentados ou se tinha a obrigação jurídica de examinar sua regularidade. Há uma passagem de Teofrasto sobre a cidade de 
Enos em que sugere ser suficiente uma declaração das partes ao magistrado para garantir a validade do ato e a responsabilidade. No entanto, Cícero, em seu discurso Pro Flacco: de dolo malo et fraude, fala de um processo ocorrido em Pérgamo, na Ásia-Menor, em que o magistrado teve o poder de recusar o registro de um ato reconhecido como vicioso.

\begin{abstract}
[...] um romano chamado Decranus, que desejoso de se apropriar dos bens de duas mulheres de Pérgamo, faz de Polemócrates, seu cúmplice, tutor de ambas, e compra dele, em nome de suas pupilas, e por um preço irrisório, os bens que almejava. Mas essas vendas foram acusadas de fraudulentas por um certo Dion, sem dúvida um parente das duas mulheres. A instância, dirigida contra Polemócrates, é levada diante dos juízes gregos de Apolonide que, julgando segundo a lei grega, condenaram Polemócrates a reparações civis, e anularam, consequentemente, os atos de venda, assim como as transcrições que Decranus fizera em Apolonide. Como só há coisa julgada entre Dion e Polemócrates, Decranus não é atingido pelo julgamento. Apesar dos juízes de Apolonide terem anulado a transcrição feita na cidade, Decranus, querendo renovar a formalidade, se dirige à cidade de Pérgamo, capital judiciária da região a qual pertencia Apolonide. Mas os habitantes de Pérgamo, cuja atenção fora despertada, não admitem a transcrição. Pode-se concluir deste recito que o magistrado encarregado da transcrição podia se recusar a registrar um título manifestadamente nulo, como aquele de Drécanus, cuja nulidade foi pronunciada por uma sentença judiciária (CÍCERO, 1964, s/p).
\end{abstract}

Mas é preciso não criar uma imagem idealizada do sistema da anagrafe, das transcrições fundiárias, no que concerne a proteção dos direitos de terceiros. Em Atenas, diferentemente de Tinos, onde os registros ganharam um incrível detalhamento de informações, os registros não informavam, por exemplo, se o vendedor havia adquirido regularmente o imóvel, ou seja, "[...] se havia pago seu preço de venda, condição necessária da transferência de propriedade", apesar de poder saber se o bem já fora alienado alguma vez (BEAUCHET, 1897, p. 333). Os terceiros também não podiam saber, ao consultar os registros, se havia taxas pendentes, contendo apenas as informações relevante do ponto de vista fiscal.

Sua principal utilidade era para o comprador. O anagrafe era a prova decisiva de seu direito de propriedade, à condição de não haver dúvidas sobre a identidade do imóvel. É certo que isso nem sempre ocorria, haja vista a pouca precisão dos registros e, o mais importante, não ter ocorrido nenhuma oposição de terceiros durante o período prescritos de exposição dos cartazes, fato que anulava qualquer possibilidade de crítica à alienação.

\title{
CONCLUSÃo
}

A criação do direito privado na Grécia clássica está diretamente vinculada à consolidação das instituições e prática democráticas. Mais ainda, foi possível verificar que os princípios da democracia da palavra, falada e escrita, da publicidade e da igualdade, compreendida a partir das noções de equilíbrio, justa medida e proporcionalidade, condicionaram o conteúdo mesmo das leis e das práticas judiciais no direito privado grego.

Analisou-se, especificamente, os sistemas de publicidade que, a depender da cidade e do momento histórico, acompanhavam todo e qualquer ato de alienação de propriedade. E apesar da grande variedade de formas assumidas por estes sistemas, o objetivo era sempre o mesmo: evitar a fraude, proteger o direito de terceiros sobre a propriedade vendida, tornando pública tanto a intenção de compra e venda quanto o registro da transação. O mais importante e completo destes sistemas foi a anagrafe, tipo de registro fundiário que prosperou sobretudo em Tinos e Atenas. Mas o importante é destacar que, independentemente do sistema adotado, as transferências de propriedade só ganhavam legitimidade jurídica quando submetidas ao conhecimento público. 
Inexistente no direito privado romano, que irá contar, no auge da sociedade republicana, apenas com as poucas e imperfeitas informações registradas no censo, as inscrições fundiárias gregas certamente inspiraram muitos códigos civis modernos, que passaram a adotar tais registros no final do séc. XIX, acompanho o renascimento das repúblicas na era moderna.

Há ainda muito por explorar e descobrir, haja vista a pluralidades de áreas do direito privado grego ainda não submetidas a um estudo sistemático. Ludovic Beauchet, como vimos, há mais de cem anos, escreveu sobre direito de família, direito de propriedade e direito das obrigações, numa obra ainda não traduzida nem analisa pela historiografia jurídica brasileira. Este pequeno artigo representa uma modesta contribuição para o trabalho de análise e divulgação das criações jurídicas gregas no campo do direito privado, e da sua presença no direito contemporâneo, inspirado sobremaneira pelo desejo de difundir os valores democráticos.

\section{REFERÊNCIAS}

ARISTÓTELES. A constituição de Atenas. São Paulo: Edipro, 2012.

A política. Rio de Janeiro: Nova Fronteira, 2011.

ARNAOUTOGLU. Leis da Grécia antiga. São Paulo: Odysseus, 2003.

BEAUCHET, Ludovic. Histoire du droit privée de la République athénienne. vol. 3. Paris: Librairie Marescq Ainé, 1897.

BRANDÃO, Cláudio. O direito grego clássico. In: História do direito e do pensamento jurídico em perspectiva. São Paulo: Atlas, 2012.

CÍCERO. The Speeches with an English Translation in Catilina I - IV: Pro-Murena, Pro Sulla, Pro-Flacco. London: Loeb Classical Library, 1964.

COULANGE, Faustel de. A cidade antiga: estudo sobre o culto, o direito e as instituições da Grécia e de Roma. São Paulo: Editora Revista dos Tribunais, 2011.

FOUCAULT, Michel. Aulas sobre a vontade de saber. São Paulo: Martins Fontes, 2014.

GERNET, Louis. Droit et institutions em Grèce antique. Paris: Flammarion, 1982.

Anthropologie de la Grèce antique. Paris: Flammarion, 2002.

. Recherches sur le développement de la pensée juridique et morale em Grèce. Paris: Albin Michel, 2001.

GILISSEN, John. Introdução histórica ao direito. Lisboa: Fundação Calouste Gulbenkian, 2013.

HESÍODO. Os trabalhos e os dias. São Paulo: Iluminuras, 1990.

JAEGER, Werner. A Paidéia: a formação do homem grego. São Paulo: Martins Fontes, 1986.

PLATÃO. A República. Lisboa: Fundação Calouste Gulbenkian, 1989.

RIBEIRO, Darcy. O processo civilizatório. Rio de Janeiro: Companhia das Letras, 2002.

VERNANT, Jean-Pierre. As origens do pensamento grego. Rio de Janeiro: Ed. Bertrand Brasil, 1992.

Recebido em: 17 maio 2017.

Aceito em: 12 dez. 2017. 